\title{
A Study on the Biological Activity of Commonly Consumed Spring Herbs in Korea
}

\author{
Hee-Jae Chung ${ }^{1}$, Ae-Jung Kim ${ }^{2 *}$ \\ ${ }^{1}$ Department of Alternative Medicine, Kyonggi University, Seoul, Korea \\ ${ }^{2}$ Department of Nutrition Therapy, Graduate School of Alternative Medicine, Kyonggi University, Seoul, Korea
}

\author{
*Corresponding author: Ae-Jung Kim, \\ Department of Nutrition Therapy, Graduate \\ School of Alternative Medicine, Kyonggi \\ University, 24, Kyonggidae-ro, 9-gil, \\ Seodaemoon-gu, Seoul 03746, Korea \\ Tel.: +82 23905044 \\ Fax: +8223905078 \\ Email: aj5249@naver.com
}

Received October 29, 2021

Revised November 09, 2021

Accepted December 02, 2021

Published December 30, 2021

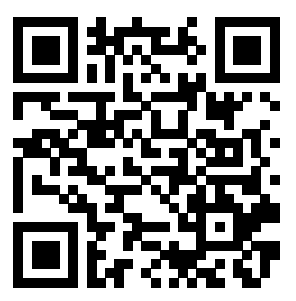

\begin{abstract}
Purpose: This study was conducted to study the superiority of Korean spring herbs by selecting eight spring herbs that are commonly consumed in Korea and evaluating their biological activity. Methods: Antioxidant (total polyphenol content, total flavonoid content, 1,1-diphenyl-2-picrylhydrazyl (DPPH) radical scavenging activity and 2,2'-azino-bis-3-ethylbenzothiazoline-6-sulfonic acid (ABTS) radical scavenging activity) and enzyme activities ( $\alpha$-glucosidase inhibitory activity and angiotensin converting enzyme (ACE) inhibitory activity) were measured using the hot-water extract of the selected spring herbs. Results: In case of total polyphenol content, the shepherd's purse, daylily, and gomchwi took first, second, and third place. In case of total flavonoid content, rape, shepherd's purse and mugwort took first, second, and third place, and in case of DPPH radical scavenging activity, shepherd's purse, daylily, and rape took first, second, and third place. In case of ABTS radical scavenging activity, the shepherd's purse, mugwort and rape took first, second, and third place. In case of $\alpha$-glucosidase inhibitory activity, mugwort, gomchwi, and wild garlic were classified in the first, second, and third place. Lastly, Korean angelica tree, rape, and wild garlic were classified in the first, second, and third, in case of ACE inhibitory activity. Conclusion: From these results, among the selected spring herbs, the shepherd's purse and rape showed exceptional effects in antioxidant activity, mugwort in antidiabetic activity, and Korean angelica tree sprout in antihypertensive activity, respectively. Therefore, the present study is expected to provide basic data for future development of foods using spring herbs to remedy lifestyle-related diseases.
\end{abstract}

Keywords: Spring herbs, Lifestyle disease, Dietary lifestyle, Antioxidant activity, Enzyme activity

\section{Introduction}

최근 우리나라는 Covid-19 펜데믹으로 인한 비대면의 확산으로 배달 및 온라인 시장이 활성화됨에 따라 식생활 패턴이 급변하고 있 다. Home meal replacement (HMR)식품, 배달음식 등 이전과는 다 른 형태의 외식문화가 자리잡고 있으며(Seo \& Kim, 2021), 외부활 동이 자유롭지 않고, 헬스장과 같은 운동 시설들의 제한적인 폐쇄 가 이어지면서 국민들의 운동량이 지속적으로 감소하고 있다(Kwon, 2020). KOSIS (2020)는 BMI가 25 이상인 한국인이 2008년 20\%에 서 2020 년에는 3 명 중 1 명 꼴인 $30.7 \%$ 로 급증하였고 약 10 년 사이
에 $10 \%$ 이상 비만이 증가하였다고 보고하였다(KOSIS, 2020). 비만 과 함께 당뇨병, 고혈압, 심혈관질환과 같은 생활습관병 또한 증가 추세여서 국가 전체의 문제로 여겨지고 있다(Yang \& Lee, 2015).

한국인의 식생활과 밀접한 채소류는 비타민, 무기질, 식이섬유 등의 영양소가 풍부하며, 항산화 물질로 알려진 페놀 화합물 등의 phytochemical이 다량 함유되어 있어 채소의 섭취량이 많을수록 노 화 촉진의 직·간접적인 원인으로 알려진 활성산소 제거에 우수한 능 력을 보인다(Kim et al., 2018). 이는 면역력을 향상시키고, 각종 생 활습관병을 예방하며, 노화 지연에 도움을 준다(Lee, 2005; Kim et al., 2012; Kim et al., 2018; Kim \& Lee, 2021). 
식사 패턴과 관련된 연구보고(Martínez-González \& MartínCalvo, 2013)를 살펴보면 육류 위주의 서구화된 식사패턴보다 과일 과 채소류를 많이 섭취하는 우리나라의 전통적 식사 패턴이 대사증 후군(metabolic syndrome)의 위험성을 낮추는 것으로 나타났다. 특 히 우리 선조들은 비타민과 무기질과 같은 영양섭취 불균형을 초래 하기 쉬운 나른한 봄날 약간 쓴 제철 봄나물로 입맛을 돋우어 심신 의 활력을 되찾아 춘곤증을 예방했다고 전해진다(Choi, 2009; Choi, 2015).

우리나라 봄철 나물 가운데 곰취(Ligularia Fischer)는 국화과 (Compositae) 곰취 속(Ligularia)의 다년생 초본 식물(Kim, 2016)로 곰취의 어린잎은 향취와 맛이 좋아 나물이나 쌈, 장아찌로 섭취하고 뿌리는 타박상, 요통, 진해, 거담, 객혈, 염증 등의 치료에 사용되어 왔다(Bae et al., 2009). 또한, 비타민 $\mathrm{A}, \mathrm{B}_{1}, \mathrm{~B}_{2}, \mathrm{C}, \beta$-carotene과 niacin, 섬유질 등을 다량 함유하고 있어 생리활성 효과가 탁월한 것 으로 알려졌다(Choi et al., 2007; Chang et al., 2008).

냉이(Capsella bursa-pastoris L.)는 십자화과(Brassicaceae) 냉 이속(Caspella)의 두해살이풀(Kim, 2016)로 전초를 식용과 약용으 로 사용하는데(Choi et al., 2006), 다른 산채류에 비하여 단백질의 함량이 높고 비타민 $\mathrm{A}$, 칼륨, 칼슘, 철분, 아연, 셀레늄이 풍부한 알 칼리성 식품이다(Peterson, 1997). 생약명으로는 제체(薺茶)라고 하 여 전초를 달여 위궤양, 치질, 폐결핵에 사용하며, 이뇨, 혈압강하, 지사제, 건위소화제, 지혈제, 자궁출혈 및 월경 과다 치료제로도 이 용되었다(Goo, 2013).

달래(Allium monanthum)는 백합과(Liliaceae) 파속(Allium)에 속 하는 다년생 구근식물(Kim, 2016)로 생체 전체를 식용으로 사용한 다(Choi et al., 1992). 달래에는 황을 함유하고 있어 독특한 풍미를 내는 알린(allin)이 매우 풍부하다. 이는 체내 독성이나 노폐물을 제 거하여 간 해독에 탁월한 효과가 입증된 glutathione으로 전환되는 시스테인의 유도 물질로도 잘 알려져 있다(Lee, 2018). 또한, 항산 화, 항당뇨, 면역 기능 향상, 동맥 경화증, 혈류 증가, 간 기능 향상, 고지혈증 억제, 혈전 형성 억제 등의 효능을 가진 것으로 알려져 있 다(Choi et al., 1992; Oh et al., 2014).

두릅(Aralia elata Seem)은 다년생 초본 두릅나무과(Araliaceae) 로(Cha et al., 2009) 두릅나무(참두릅과 민두릅)와 땅두릅의 새순 과 어린잎은 주로 데쳐서 나물로 먹고, 나무껍질과 뿌리는 전통적 으로 약용으로 쓰여왔다. 두릅에는 saponin, alkalloide, oleanolic acid, sitosterol, triterpenoid glycoside, choline, ascorbic acid, $\beta$-carotene, asparaginic acid 등이 풍부하여(Lee, 2005; Cha et al., 2009) 혈액순환, 활력 증진, 암을 유발하는 물질인 nitroamine 을 억제하며, 강장제, 위궤양, 부정맥, 관절염, 고혈압 및 당뇨병 제 제로 사용되어 왔다(Xu et al., 1997; Li \& Lu, 2009). 특히, 비타민 $\mathrm{B}_{1}$ 이 많이 함유되어 있어 면역력을 강화하고, 알코올 흡수 저해 효과 및 항산화 효과가 있다(Chung \& Jung, 2003).

봄동(Brassica rapa L.)은 십자화과(Brassicaceae) 배추 속
(Brassica)에 속하는 두해살이 잎채소(Kim, 2016)로 겨울철 노지에 파종하고 봄에 수확하는 배추 종류 중 하나이다(Choi et al., 2015; Seo et al., 2015). 봄동은 아미노산, 식이섬유소, 칼슘, 철분 등의 영양성분이 일반 배추에 비해 2 배 가까이 풍부한 것으로 알려져 있 으며, 특히 $\beta$-carotene의 경우, 6 배 이상 높은 함량을 가지고 있다 (RDA, 2016). 또한, 독특한 생리활성 물질인 glucosinolate가 풍부 하게 함유되어 있는데(Hwang, 2010), 배추를 비롯한 십자화과 채 소에 존재하는 glucosinolate의 분해물질인 indole-3-carbinol, sulforaphane, phenyl isothiocyanate들의 암 예방 효능도 보고되었 다(Hwang \& Lee, 2006; Clarke et al., 2008; Hayes et al., 2008).

쑥(Artemisia Princeps pampanim)은 국화과(Compositae) 쑥 속(Artemisia)의 다년생 초본식물로(Kim, 2016), 봄나물 중에 비 타민 $\mathrm{A}$ 와 칼륨 함량이 가장 많은 알칼리성 식품이며, 감기 예방, 피로 해소, 항암 효과가 뛰어나다고 알려졌다(Choi, 2015). 또한, angiotensin 전환 효소의 작용을 저해시켜 고혈압을 예방(Han et al., 2009)하고, 혈액순환, 부인병 예방, 폐 기능 강화, 항균, 체중 감 량 등에 효과적인 것으로 알려졌다(Choi, 2015; Han et al., 2009).

원추리(Hemerocallis fulva L.)는 백합과(Lilliaceae) 원추리 속 (Hemerocallis)에 속한 여러해살이풀(Kim, 2016)로, 주로 봄철 어 린 잎을 따서 물에 데쳐 나물로 섭취하는데 단맛을 느끼고, 좋은 식 감을 위해서는 단시간에 데치는 것이 좋다(Ham, 2011). 비타민 A, $\mathrm{C}$ 가 많이 함유되어 있어 발암성 물질의 억제 효과가 높으며, 전초 에는 이뇨 작용, 항염증 작용, 지혈 작용이 있다. 또한, 해독 작용 도 뛰어나서 폐결핵, 빈혈, 황달, 변비, 소변불통, 자양강장제로도 쓰였다(Ahn, 2009). 칼슘, 인, 철분 외 유기산, adenine, arginine, asparagine, choline, colchicine 등의 아미노산도 다량 함유되어 있 다(Ham, 2011).

유채(Brassica napus L.)는 십자화과(Crueiferae) 운대 속 (Brassica)에 속하는 1-2 년생 초본 식물로(Kim et al., 2015), 40\% 의 지방과 25-30\%의 단백질을 함유한 세계 5 대 유지 자원식물이다 (Kim, 2016). 어린 유채는 연한 잎과 줄기로 김치를 담가 먹고, 삶 아서 나물로 먹거나 국을 끓여 먹기도 한다(Goo, 2013). 또한 유채 꽃은 눈을 밝게 하고 독을 차단하며 지혈 작용이 있다(Lee et al., 2011). 유채 종자의 지질에는 오메가-6 지방산인 linoleic acid와 오 메가-3 지방산인 $\alpha$-linolenic acid의 비율이 2:1로 존재하여 면역 력, 항염증 등에 효과를 가지고 있다(McDonald, 2004; Lee et al., 2014).

이와 같이 우리나라 봄나물류는 한국인의 먹거리임에도 불구하고 과학적으로 생리활성을 검증한 연구가 아직까지 매우 드문 실정이 다. 따라서 본 연구에서는 국내에서 다소비 되고 있는 봄나물류 8종 을 선정하고 생리활성(항산화 및 효소활성)을 평가하여 우리나라 봄 나물의 우수성을 재조명하고자 하였다. 


\section{Methods}

\section{1. 실험재료}

본 실험에서 사용된 한국인 다소비 8종의 봄나물류(곰취, 냉이, 달 래, 두릅, 봄동, 쑥, 원추리, 유채)는 가락동 농수산물 시장(Garakdong, Seoul)에서 일괄 구매하여 잘 다듬어 씻은 후 증류수로 헹구어 채반에 밭쳐 $10 \mathrm{~min}$ 간 자연 탈수하여 표면의 물기를 제거하고 시료 로 사용하였다.

\section{2. 추출물 제조}

한국인 다소비 8종의 봄나물류를 각 시료 $100 \mathrm{~g}$ 당 10 배의 증류 수를 첨가한 후 환류 냉각관을 부착한 $80^{\circ} \mathrm{C}$ 의 heating mantle $(\mathrm{HM}$ 250C, Sercrim Lab Tech, Seoul, Korea)에서 $2 \mathrm{~h}$ 추출 시킨 후 3 차 례 여과(No. 3, Whatman, Maidstone, England)하여 분석용 시료로 사용하였다.

\section{3. 생리활성 측정}

1) Total polyphenol content

한국인 다소비 8종의 봄나물류의 열수 추출 시료들의 총 폴리페놀 함량은 F-C 시약을 사용하는 Singleton \& Rossi (1965)의 방법을 변 형하여 측정하였다. 추출물 $350 \mu \mathrm{L}$ 에 $50 \%$ Folin-Ciocalteu (Sigma Chemical Co., USA) 시약 $70 \mu \mathrm{L}$ 를 가하여 실온에서 $3 \mathrm{~min}$ 간 정치 한 다음, $2 \%(\mathrm{w} / \mathrm{v}) \mathrm{Na}_{2} \mathrm{CO}_{3}$ 용액 $350 \mu \mathrm{L}$ 를 첨가하여 $60 \mathrm{~min}$ 간 반 응시킨 다음 $750 \mathrm{~nm}$ 에서 microplate reader (Infinite M200 Pro; Tecan, Austria)를 이용하여 흡광도를 측정하였다. 총 폴리페놀 함량 은 tannic acid를 이용하여 작성한 표준 곡선으로부터 구하였다.

\section{2) Total flavonoid content}

한국인 다소비 8종의 봄나물류의 열수 추출 시료들의 총 플라보 노이드 함량은 Davis (1947)의 방법을 변형하여 측정하였다. 추출물 $100 \mu \mathrm{L}$ 에 diethylene glycol $1,000 \mu \mathrm{L}$ 를 첨가하고 다시 $1 \mathrm{~N}-\mathrm{NaOH}$ 용액 $10 \mu \mathrm{L}$ 를 첨가한 후 $37^{\circ} \mathrm{C}$ 에서 $1 \mathrm{~h}$ 반응시킨 후 $420 \mathrm{~nm}$ 에서 microplate reader (Infinite M200 Pro; Tecan)를 이용하여 흡광도 를 측정하였다. 총 플라보노이드 함량은 quercetin을 이용하여 작성 한 표준 곡선으로부터 구하였다.

\section{3) DPPH radical scavenging activity}

한국인 다소비 8종의 봄나물류의 열수 추출 시료들의 1 , 1-diphenyl-2-picrylhydrazyl (DPPH; Sigma-Aldrich) radical 소 거능은 Blois (1958)의 방법을 변형하여 다음과 같이 실시하였다. 시 료 $100 \mu \mathrm{L}$ 에 $1.5 \times 10^{-4} \mathrm{M} \mathrm{DPPH}$ 용액 $100 \mu \mathrm{L}$ 를 가하여 실온의 암실 에서 $30 \mathrm{~min}$ 간 정치한 다음 $517 \mathrm{~nm}$ 에서 microplate reader (Infinite M200 Pro; Tecan)를 이용하여 흡광도를 측정하였다.
4) ABTS radical scavenging activity

한국인 다소비 8종의 봄나물류의 열수 추출 시료들의 2,2'-azinobis-3-ethylbenzothiazoline-6-sulfonic acid (ABTS; SigmaAldrich) radical소거능은 Fellegrini et al. (1999)의 방법으로 측정하 였다. ABTS 7.4 mM과 potassium persulphate $2.6 \mathrm{mM}$ 을 같은 비 율로 섞어 하루 동안 암소에 방치하여 ABTS 양이온을 형성시킨 다음 $732 \mathrm{~nm}$ 에서 흡광도 값이 $0.70 \pm 0.02$ 가 되도록 $1 \times \mathrm{PBS}$ 로 희석하 였다. 희석된 ABTS용액 $190 \mu \mathrm{L}$ 에 추출물 시료 $10 \mu \mathrm{L}$ 를 가하여 10 $\min$ 간 정치한 다음 $732 \mathrm{~nm}$ 에서 microplate reader (Infinite M200 Pro; Tecan)를 이용하여 흡광도를 측정하였다.

5) $\alpha$-Glucosidase inhibitory activity

한국인 다소비 8종의 봄나물류의 열수 추출 시료의 $\alpha$-glucosidase 저해 활성은 Li et al. (2005)의 방법을 변형하여 측정하였다. 반 응 혼합물의 총 부피는 $200 \mu \mathrm{L}$ 로 맞추었다. 각각의 well에 sample $50 \mu \mathrm{L}$ 과 $100 \mathrm{mM}$ phosphate buffer ( $\mathrm{pH}$ 6.8) $90 \mu \mathrm{L}$ 을 넣은 다음 $\alpha$-glucosidase (10 mM phosphate buffer (pH 6.8)에 녹인 1 unit/ $\mathrm{mL}$ 농도) $20 \mu \mathrm{L}$ 를 넣고 $37^{\circ} \mathrm{C}$ 에서 $15 \mathrm{~min}$ 동안 preheating 시켰 다. 기질로 사용된 $2.5 \mathrm{mM} \mathrm{p}$-nitrophenyl $\alpha-\mathrm{D}$-glucopyranoside ( $p \mathrm{NPG}$ )는 $100 \mathrm{mM}$ phosphate buffer ( $\mathrm{pH}$ 6.8)에 녹여 $40 \mu \mathrm{L}$ 를 첨가하여 $37^{\circ} \mathrm{C}$ 에서 $25 \mathrm{~min}$ 간 incubation 시킨 다음 $405 \mathrm{~nm}$ 에서 microplate reader (Infinite M200 Pro; Tecan)를 이용하여 흡광도를 측정하여 다음 공식으로 저해율을 산출하였다.

$\alpha$-Glucosidase inhibitory activity $(\%)=[1-\{(\mathrm{As}-\mathrm{AsB}) /(\mathrm{Ac}-\mathrm{AcB})\}]$ $\times 100$

As: 효소와 시료를 모두 첨가한 반응용액의 흡광도 $\mathrm{AsB}:$ 시료만 첨가한 반응용액의 흡광도

$\mathrm{Ac}$ : 효소만 첨가한 반응용액의 흡광도

$\mathrm{ACB}:$ 효소와 시료를 모두 첨가하지 않은 용액의 흡광도

6) Angiotensin convenrting enzyme (ACE) inhibitory activity 한국인 다소비 8종의 봄나물류의 열수 추출 시료의 angiotensin converting enzyme (ACE) 저해활성은 Cushman \& Cheung (1971) 의 방법을 다소 변형하여 측정하였다. 기질인 hippury-L-histidylhistidyl-L-leucine (HHL) (8.3 mM)의 제조방법은 sodium chloride 를 $300 \mathrm{mM}$ 함유한 $50 \mathrm{mM} \mathrm{HCL} \mathrm{buffer} \mathrm{(pH} \mathrm{8.3)에} \mathrm{녹여} \mathrm{준비한} \mathrm{후}$ $\mathrm{ACE}$ 효소 $50 \mu \mathrm{L}, \mathrm{HHL} 150 \mu \mathrm{L}$ 와 sample 시료 $50 \mu \mathrm{L}$ 를 혼합하였다. 대조군은 sample 시료 대신 증류수 $50 \mu \mathrm{L}$ 를 첨가하여 $37^{\circ} \mathrm{C}$ 에서 30 $\min$ 반응시킨 다음, $1 \mathrm{~N} \mathrm{HCl} 250 \mu \mathrm{L}$ 를 첨가하여 반응을 중지시켰다. 여기에 ethyl acetate $500 \mu \mathrm{L}$ 를 가하여 $15 \mathrm{~s}$ 교반한 다음 3,000 rpm 에서 $5 \mathrm{~min}$ 원심 분리를 시켜 상등액 $200 \mu \mathrm{L}$ 를 취하였다. 상등액을 $120^{\circ} \mathrm{C}$ 에서 $30 \mathrm{~min}$ 가열하여 건조시킨 다음 증류수 $1 \mathrm{~mL}$ 를 가하여 용해시켜 ELISA microplate reader (Infinite M200 Pro; Tecan)를 이용하여 $228 \mathrm{~nm}$ 에서 흡광도를 측정한 다음 공식을 이용하여 저해 
율을 산출하였다.

ACE inhibitory activity $(\%)=[1-\{($ As-AsB $) /(A c-A c B)\}] \times 100$

As: 효소와 시료를 모두 첨가한 반응용액의 흡광도

$\mathrm{AsB}$ : 시료만 첨가한 반응용액의 흡광도

$\mathrm{Ac}$ : 효소만 첨가한 반응용액의 흡광도

$\mathrm{AcB}:$ 효소와 시료를 모두 첨가하지 않은 용액의 흡광도

\section{4. 통계처리}

모든 자료는 SPSS statistics 24 (SPSS Institute, USA)를 이용하 여 평균과 표준편차를 구하고 통계분석을 실시하였다. 각각의 샘플 간의 유의성은 one-way ANOVA를 실시한 후 유의 수준을 $5 \%$ 로 설 정하여 Duncan's multiple range test로 사후 검정을 하였다.

\section{Results and Discussion}

\section{Total polyphenol 함량}

천연 항산화제로서의 기능이 잘 알려진 식물체에는 2 차 대사산물
의 하나인 페놀성 물질이 다량 함유되어 있으며, 식물 유래 페놀성 물 질은 콜레스테롤 저하 작용, 항암 및 항산화 작용, 당뇨병 예방 등 다 양한 생리활성 기능을 가지고 있다(Kim et al., 2000).

한국의 다소비 8 종 봄나물류의 총 polyphenol 함량을 분석한 결과 는 Table 1에 제시한 바와 같다. 냉이(CB-P: 101.71 $\pm 1.07 \mathrm{mg} \mathrm{TAE} /$ $\mathrm{g})$ 의 총 polyphenol 함량이 가장 높았으며, 그 다음으로 원추리(HFL: $71.47 \pm 1.15 \mathrm{mg} \mathrm{TAE} / \mathrm{g}$ ), 곰취(LF: $65.58 \pm 0.55 \mathrm{mg} \mathrm{TAE} / \mathrm{g}$ ), 두릅 (AS: $42.53 \pm 0.92 \mathrm{mg} \mathrm{TAE} / \mathrm{g}$ ), 봄동(BRL: $28.65 \pm 10.17 \mathrm{mg} \mathrm{TAE} /$ $\mathrm{g})$, 쑥(APP: $23.56 \pm 0.03 \mathrm{mg} \mathrm{TAE} / \mathrm{g}$ ), 유채(BNL: $16.99 \pm 0.04 \mathrm{mg}$ $\mathrm{TAE} / \mathrm{g}$ ), 달래(AM: $9.32 \pm 0.14 \mathrm{mg} \mathrm{TAE} / \mathrm{g}$ )의 순으로 높게 나타났다.

Lee et al. (2014)의 연구에서 석창포, 두릅순, 냉이, 민들레의 총 폴리페놀 함량을 분석한 결과, 석창포, 두릅순, 냉이, 민들레의 순 으로 높게 나타났다. 본 연구에서는 냉이, 두룹의 순으로 총 폴리페 놀 함량이 높게 나타나 상이한 결과를 보였다. 이러한 결과는 봄나물 의 채취 시기, 재배지역 등의 차이 때문으로 추출할 수 있다. 또한, Riaz et al. (2021)의 연구에 따르면 파키스탄의 냉이에 함유된 파이 토케미컬 중 페놀의 함량은 $1.56 \times 10^{-4} \mathrm{mg} \mathrm{GAE} / \mathrm{g}$ 으로 나타났으며, Salayová et al. (2021)의 연구에서 민간요법으로 널리 사용되는 약

Table 1. Total polyphenol content of the eight Korean spring herbs

\begin{tabular}{lc}
\hline Samples $^{1)}$ & ${\text { Total polyphenol contents }\left(\mathrm{mg} \mathrm{TAE}^{2)} / \mathrm{g}\right)}{ }^{2}$ \\
CB-P & $65.58 \pm 0.55^{3) b 4)}$ \\
AM & $101.71 \pm 1.07^{\mathrm{a}}$ \\
AS & $9.32 \pm 0.14^{\mathrm{f}}$ \\
BCL & $42.53 \pm 0.92^{\mathrm{c}}$ \\
APP & $28.65 \pm 10.17^{\mathrm{d}}$ \\
HFL & $23.56 \pm 0.03^{\mathrm{d}}$ \\
BNL & $71.47 \pm 1.15^{\mathrm{b}}$ \\
\hline
\end{tabular}

${ }^{1)} \mathrm{LF}$, Gomchwi (Ligularia fischeri); CB-P, Shepherd's purse (Capsella bursa-pastoris L.); AM, Wild garlic (Allium monanthum); AS, Korean angelica tree (Aralia elata seem); BCL, Bomdong (Brassica competris L.); APP, Mugwort (Artemisia princeps pampanim); HFL, Day lily (Hemerocallis fulva L); BNL, Rape (Brassica napus L.); ${ }^{2} \mathrm{TAE}$, tannic acid equivalent; ${ }^{3)}$ Mean $\pm \mathrm{SD}\left(\mathrm{n}=3\right.$ ); ${ }^{4}$ Different superscripts are significantly (a-f) different by Duncan's multiple range test at $p<0.05$.

Table 2. Total flavonoid content of the eight Korean spring herbs

\begin{tabular}{lc}
\hline Samples $^{1)}$ & Total flavonoid content $\left(\mathrm{mg} \mathrm{QE}^{2)} / \mathrm{g}\right)$ \\
LF & $115.78 \pm 3.78^{3) \mathrm{d} 4)}$ \\
CB-P & $229.47 \pm 3.29^{\mathrm{b}}$ \\
AM & $8.30 \pm 0.48^{\mathrm{g}}$ \\
AS & $57.84 \pm 1.89^{\mathrm{e}}$ \\
BCL & $52.48 \pm 4.16^{\mathrm{f}}$ \\
APP & $215.22 \pm 2.40^{\mathrm{c}}$ \\
HFL & $2.39 \pm 0.63^{\mathrm{h}}$ \\
BNL & $242.28 \pm 3.80^{\mathrm{a}}$ \\
\hline
\end{tabular}

1)LF, Gomchwi (Ligularia fischeri); CB-P, Shepherd's purse (Capsella bursa-pastoris L.); AM, Wild garlic (Allium monanthum); AS, Korean angelica tree (Aralia elata seem); BCL, Bomdong (Brassica competris L.); APP, Mugwort (Artemisia princeps pampanim); HFL, Day lily (Hemerocallis fulva L.); BNL, Rape (Brassica napus L.); ${ }^{2)} \mathrm{QE}$, quercetin acid equivalent; ${ }^{3)} \mathrm{Mean} \pm \mathrm{SD}(\mathrm{n}=3) ;{ }^{4}$ Different superscripts are significantly $(\mathrm{a}-\mathrm{h})$ different by Duncan's multiple range test at $p<0.05$. 
용식물 5 종의 총 폴리페놀 함량을 분석한 결과, 냉이의 경우 $0.46 \pm$ $0.03 \mathrm{mg} \mathrm{GAE} / \mathrm{mL}$ 로 나타났다. Hong et al. (2007)의 연구에서 약 쑥의 용매별 총 폴리페놀 함량을 분석한 결과, 약쑥 열수 추출물에서 $213.83 \pm 24.58 \mu \mathrm{g} / \mathrm{mg}$ 으로 나타나 본 실험에서 사용한 쑥에서 더욱 높은 항산화능을 확인할 수 있다.

\section{Total flavonoid 함량}

식물체에서 광합성을 통하여 생성된 플라보노이드는 $\mathrm{di}(\mathrm{bis})$ phenyl propane의 구조를 가지는 페놀계 화합물의 총칭으로, 비타민 $\mathrm{P}$ 라 불리는 노란색 계통의 색소이다(Kim et al., 2012). 플라보노이 드는 활성산소종을 효과적으로 제거하여 항산화능이 우수하다고 알 려져 있으며, 폴리페놀과 마찬가지로 항바이러스, 항염증, 항암 등에 효과가 있는 것으로 알려져 있다(Pietta, 2000; Kim et al., 2020).

한국의 다소비 8종 봄나물류의 총 flavonoid 함량을 분석한 결과 는 Table 2에 제시한 바와 같다. 유채(BNL: $242.28 \pm 3.80 \mathrm{mg} \mathrm{QE} /$ $\mathrm{g})$ 의 총 flavonoid 함량이 가장 높았으며, 그 다음으로 냉이(CB-P: $229.47 \pm 3.29 \mathrm{mg} \mathrm{QE} / \mathrm{g})$, 쑥(APP: $215.22 \pm 2.40 \mathrm{mg} \mathrm{QE} / \mathrm{g})$, 곰취 (LF: $115.78 \pm 3.78 \mathrm{mg} \mathrm{QE} / \mathrm{g})$, 두릅(AS: $57.84 \pm 1.89 \mathrm{mg} \mathrm{QE} / \mathrm{g})$, 봄동(BRL: $52.48 \pm 4.16 \mathrm{mg} \mathrm{QE} / \mathrm{g})$, 달래(AM: $8.30 \pm 0.48 \mathrm{mg} \mathrm{QE} /$ $\mathrm{g})$, 원추리(HFL: $2.39 \pm 0.63 \mathrm{mg} \mathrm{QE} / \mathrm{g})$ 의 순으로 높게 나타났다.

Choi et al. (2004)의 연구에서 여러 종류의 쑥(사자발쑥, 황해쑥, 인진쑥) 에탄올 추출물의 플라보노이드 함량을 비교해 본 결과, 사자 발쑥이 $6.1 \mathrm{mg} \%$, 황해쑥이 $3.6 \mathrm{mg} \%$, 인진쑥이 $1.8 \mathrm{mg} \%$ 의 순으로 높은 플라보노이드 함량을 나타냈다. 또한, Hong et al. (2007)의 연 구 결과, 약쑥의 용매별 총 플라보노이드 함량을 분석한 결과, 약쑥 열수 추출물에서 $74.70 \pm 4.04 \mu \mathrm{g} / \mathrm{mg}$ 으로 나타나 본 실험에서 사용 한 쑥에서 더욱 높은 항산화능을 확인할 수 있다.

\section{DPPH radical 소거능}

유리 radical은 인체 내에서 지질 또는 단백질 등과 결합하여 산 화를 일으키기 쉽다. DPPH radical 소거능은 불안정한 유리기에 환
원 기능을 가진 protonion을 제공하여 안정화를 유도하여 생체 내에 서 발생하는 불안정하고 유해한 유리기를 안정화시키는 역할을 한다 (Kim et al., 2012). 따라서 특정 물질이 생체의 생리작용 혹은 산화 작용 때문에 발생하는 hydroxyl radical 혹은 superoxide radical 등을 제거하는 항산화능을 평가하는 지표로 사용된다(Lee et al., 2011).

한국의 다소비 8종 봄나물류의 DPPH radical 소거능을 분석한 결 과는 Table 3 에 제시한 바와 같다.

냉이(CB-P: $86.80 \pm 0.94 \%)$ 의 DPPH radical 소거능이 가장 높았 으며, 그 다음으로 원추리(HFL: 85.39 $0.29 \%)$, 유채(BNL: 80.46

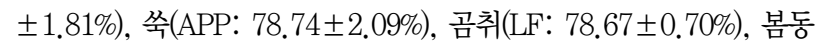

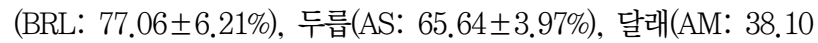
$\pm 1.11 \%)$ 의 순으로 높게 나타났다.

Nam et al. (2017)의 연구 결과, 곰취의 DPPH radical 소거능의 $\mathrm{IC}_{50}$ 값이 $28.2 \pm 0.04 \mu \mathrm{g} / \mathrm{mL}$ 로 나타났다. 여러 종류의 쑥(사자발쑥, 황해쑥, 인진쑥) 에탄올 추출물의 DPPH radical 소거능을 비교해 본 결과, 황해쑥이 $24.4 \%$, 사자발쑥이 $19.0 \%$, 그리고 인진쑥이 $14.3 \%$ 으로 나타났다(Choi et al., 2004). 또한, Salayová et al. (2021)의 연 구에 따르면, 민간요법으로 널리 사용되는 약용식물 5 종의 $\mathrm{DPPH}$ radical 소거능을 분석한 결과, 냉이의 경우 $92.97 \pm 0.04 \%$ 로 본 연구 결과와 유사한 높은 radical 소거능을 보였다.

\section{ABTS radical 소거능}

ABTS radical 소거능은 potassium persulfate와 반응하여 생성 된 ABTS 유리 radical이 추출물 내의 항산화 물질에 의해 제거되어 radical 특유의 색인 청록색이 탈색되는 것을 이용하여 항산화능을 측 정할 수 있다(Lee \& Ryu, 2019).

한국의 다소비 8종 봄나물류의 ABTS radical 소거능을 분석한 결 과는 Table 4에 제시한 바와 같다.

냉이(CB-P: $93.38 \pm 0.11 \%)$ 의 ABTS radical 소거능이 가장 높

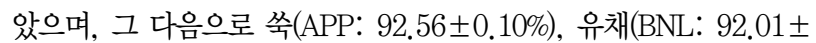

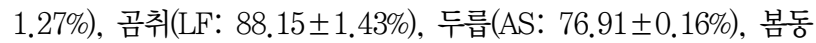

Table 3. DPPH radical scavenging activity of the eight Korean spring herbs

\begin{tabular}{lc}
\hline Samples $^{1)}$ & DPPH radical scavenging activity (\%) \\
LF & $78.67 \pm 0.70^{2)(c 3)}$ \\
CB-P & $86.80 \pm 0.94^{\mathrm{a}}$ \\
AM & $38.10 \pm 1.11^{\mathrm{e}}$ \\
AS & $65.64 \pm 3.97^{\mathrm{d}}$ \\
BCL & $77.06 \pm 6.21^{\mathrm{c}}$ \\
APP & $78.74 \pm 2.09^{\mathrm{c}}$ \\
HFL & $85.39 \pm 0.29^{\mathrm{ab}}$ \\
BNL & $80.46 \pm 1.81^{\mathrm{bc}}$ \\
\hline
\end{tabular}

${ }^{1)}$ LF, Gomchwi (Ligularia fischeri); CB-P, Shepherd's purse (Capsella bursa-pastoris L.); AM, Wild garlic (Allium monanthum); AS, Korean angelica tree (Aralia elata seem); BCL, Bomdong (Brassica competris L.); APP, Mugwort (Artemisia princeps pampanim); HFL, Day lily (Hemerocallis fulva L.); BNL, Rape (Brassica napus L.); ${ }^{2} \mathrm{Mean} \pm \mathrm{SD}(\mathrm{n}=3) ;{ }^{3}$ Different superscripts are significantly (a-e) different by Duncan's multiple range test at $p<0.05$. 


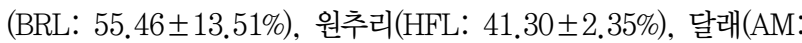
$35.59 \pm 2.22 \%)$ 의 순으로 높게 나타났다.

Kurt et al. (2018)의 연구 결과 냉이 열수 추출물의 ABTS radical 소거능 $\mathrm{IC}_{50}$ 은 $66.14 \pm 0.74 \mu \mathrm{g} / \mathrm{mL}$ 로 나타났다. 또한, Kang et al. (2017)의 연구에서 전처리 방법을 달리한 섬애약쑥 에탄올 추출물의

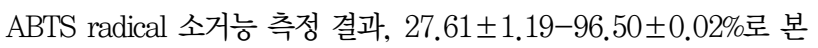
연구의 결과와 유사한 결과를 보였다.

\section{5. $\alpha$-Glucosidase 저해 활성}

$\alpha$-Glucosidase는 소장에 존재하는 포도당 분해효소로서 그 저해 제는 탄수화물의 포도당으로의 소화를 지연시켜 식사 후의 혈중 포도 당 수치를 감소시키는 역할을 한다(Maki et al., 2007). 이는 활성 물 질이 $\alpha$-glucosidase에 경쟁적으로 결합하여 효소 활성을 억제함으로 써 장내에서 당질의 소화 및 흡수를 지연시켜 혈당의 급격한 상승과 불필요한 인슐린의 분비를 억제하기 때문이다(Yong et al., 2011). 따 라서 $\alpha$-glucosidase 저해제는 당질 관련 질환을 위한 치료제 개발에 사용된다(Baron, 1998).

한국의 다소비 8종 봄나물류의 $\alpha$-glucosidase 저해 활성을 분석한
결과는 Table 5 에 제시한 바와 같다.

쑥(APP: $36.31 \pm 1.56 \%)$ 의 $\alpha$-glucosidase 저해 활성이 가장 높

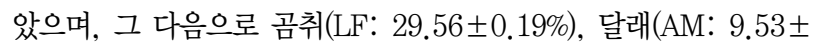
1.67\%), 냉이(CB-P: $9.10 \pm 0.06 \%$ ), 원추리(HFL: $8.53 \pm 1.19 \%)$, 두릅(AS: $8.31 \pm 1.40 \%$ ), 봄동(BRL: $8.30 \pm 0.12 \%)$, 유채(BNL: $7.52 \pm 0.79 \%)$ 의 순으로 높게 나타났다.

곰취의 $30 \%$ 주정추출물의 $\alpha$-glucosidase 저해 활성 결과, 100 $\mu \mathrm{g} / \mathrm{mL}$ 의 농도에서 $44.40 \pm 1.51 \%$ 로 나타났다(MAFRA, 2017). 또 한, $\operatorname{Kim} \& \operatorname{Kim}$ (2020)의 연구에 따르면, 개똥쑥 잎 에탄올 추출물의 $\alpha$-glucosidase 저해 활성 결과 양성대조군으로 사용된 acarbose와 비슷한 결과를 나타내 높은 항당뇨능을 확인할 수 있었다. Ahn et al. (2015)의 연구 결과, 5 종의 산채 추출물의 $\alpha$-glucosidase 저해 활성 을 비교해 보면, 그 중 다래순이 $23.7 \%$ 로 가장 높은 항당뇨 활성을 보 였다.

\section{Angiotensin converting enzyme (ACE) inhibitory activity} 혈압을 조절하는 요인 중 하나인 renin-angiotensin system은 혈 압이 감소하면 renin이 신장에서 분비되어 혈장의 angiotensinogen

\section{Table 4. ABTS radical scavenging activity of the eight Korean spring herbs}

\begin{tabular}{lc}
\hline Samples $^{1)}$ & ABTS radical scavenging activity (\%) \\
LF & $88.15 \pm 1.43^{2) b 3)}$ \\
CB-P & $93.38 \pm 0.11^{\mathrm{a}}$ \\
AM & $35.59 \pm 2.22^{f}$ \\
AS & $76.91 \pm 0.16^{\mathrm{c}}$ \\
BCL & $55.46 \pm 13.51^{\mathrm{d}}$ \\
APP & $92.56 \pm 0.10^{\mathrm{a}}$ \\
HFL & $41.30 \pm 2.35^{\mathrm{e}}$ \\
BNL & $92.01 \pm 1.27^{\mathrm{a}}$ \\
\hline
\end{tabular}

${ }^{1)}$ LF, Gomchwi (Ligularia fischeri); CB-P, Shepherd's purse (Capsella bursa-pastoris L.); AM, Wild garlic (Allium monanthum); AS, Korean angelica tree (Aralia elata seem); BCL, Bomdong (Brassica competris L.); APP, Mugwort (Artemisia princeps pampanim); HFL, Day lily (Hemerocallis fulva L.); BNL, Rape (Brassica napus L.); ${ }^{2}$ Mean $\pm S D(n=3) ;{ }^{3)}$ Different superscripts are significantly (a-f) different by Duncan's multiple range test at $p<0.05$.

Table 5. $\alpha$-Glucosidase inhibitory activity of the eight Korean spring herbs

\begin{tabular}{lc}
\hline Samples $^{1)}$ & $\alpha$-Glucosidase inhibitory activity (\%) \\
LF & $29.56 \pm 0.19^{2 / b 3)}$ \\
CB-P & $9.10 \pm 0.06^{c}$ \\
AM & $9.53 \pm 1.67^{c}$ \\
AS & $8.31 \pm 1.40^{c}$ \\
BCL & $8.30 \pm 0.12^{c}$ \\
APP & $36.31 \pm 1.56^{\mathrm{a}}$ \\
HFL & $8.53 \pm 1.19^{c}$ \\
BNL & $7.52 \pm 0.79^{\circ}$ \\
\hline
\end{tabular}

${ }^{1)} \mathrm{LF}$, Gomchwi (Ligularia fischeri); CB-P, Shepherd's purse (Capsella bursa-pastoris L.); AM, Wild garlic (Allium monanthum); AS, Korean angelica tree (Aralia elata seem); BCL, Bomdong (Brassica competris L.); APP, Mugwort (Artemisia princeps pampanim); HFL, Day lily (Hemerocallis fulva L.); BNL, Rape (Brassica napus L.); ${ }^{2}$ Mean $\pm S D(n=3) ;{ }^{3)}$ Different superscripts are significantly (a-c) different by Duncan's multiple range test at $p<0.05$. 
이 angiotensin I 으로 전환되고(Yoo et al., 2021), angiotensin converting enzyme (ACE)에 의해 angiotensin II 로 전환된다. 그 로 인해 부신피질에서 알도스테론의 분비를 촉진하고 나트륨과 수분 이 재흡수 되어 혈압을 상승시킨다(Jang, 2006). ACE 저해는 이러한 $\mathrm{ACE}$ 의 작용을 저해함으로써 신장의 혈관을 확장시켜 나트륨이 원활 하게 배출되도록 하여 혈압을 낮춘다(Corvol et al., 1995; Fujita et al., 2000).

한국의 다소비 8종 봄나물류의 $\mathrm{ACE}$ 저해 활성을 분석한 결과는 Table 6에 제시한 바와 같다.

두릅(AS: $85.25 \pm 0.46 \%)$ 의 $\mathrm{ACE}$ 저해 활성이 가장 높았으며, 그

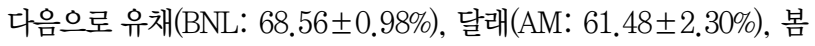
동(BRL: $37.19 \pm 3.52 \%)$, 냉이(CB-P: $33.95 \pm 0.68 \%)$, 곰취(LF: $33.15 \pm 1.60 \%)$, 원추리(HFL: $29.93 \pm 1.55 \%)$, 쑥(APP: $24.97 \pm$ $1.96 \%)$ 의 순으로 높게 나타났다.

Lee et al. (2016)의 연구 결과 참취의 열수 추출물에서 27.98土 0.72-50.79 $\pm 2.48 \%$ 의 저해율을 보였고 이는 본 실험의 결과와 유 사한 수준임을 알 수 있다.

\section{Conclusion}

우리나라에서는 오래전부터 봄에 봄나물을 섭취함으로써 비타민과 무기질과 같은 영양의 불균형을 예방하고자 섭취해 왔음에도 불구하 고 생리활성에 대한 검증 연구는 드문 실정이었다.

이에 본 연구에서는 한국인 다소비 8종의 봄나물류(곰취, 냉 이, 달래, 두릅, 봄동, 쑥, 원추리, 유채)를 선정하여 항산화 활성 (total polyphenol contents, total flavonoid contents, DPPH radical scavenging activity, ABTS radical scavenging activity) 및 효소 활 성( $\alpha$-glucosidase inhibitory activity, $\mathrm{ACE}$ inhibitory activity)을 측 정하였다.

한국인 다소비 8종의 봄나물의 총 폴리페놀 함량 측정 결과, 냉이

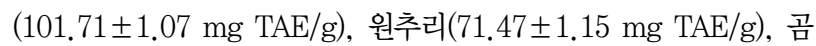

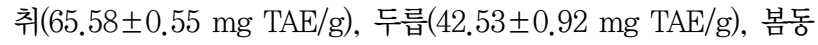

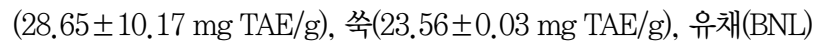
(16.99 mg TAE/g), 달래(9.32 $0.14 \mathrm{mg} \mathrm{TAE} / \mathrm{g})$ 의 순으로 높게 나 타났다. 총 플라보노이드 함량 측정 결과, 유채 $(242.28 \pm 3.80 \mathrm{mg}$

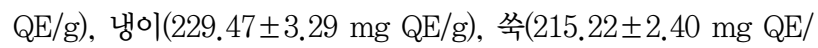

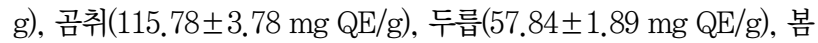
동(BRL: $52.48 \pm 4.16 \mathrm{mg} \mathrm{QE} / \mathrm{g})$, 달래 $(8.30 \pm 0.48 \mathrm{mg} \mathrm{QE} / \mathrm{g})$, 원추 리 $(2.39 \pm 0.63 \mathrm{mg} \mathrm{QE} / \mathrm{g})$ 의 순으로 높게 나타났다. DPPH radical 소

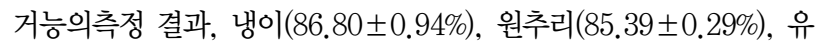

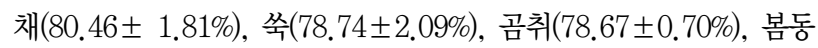

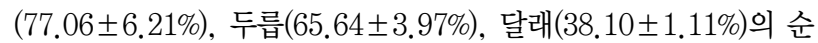
으로 높게 나타났다. ABTS radical 소거능의 측정 결과, 냉이(93.38

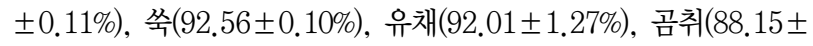

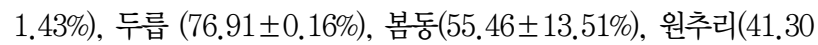

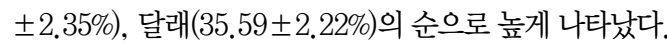

$\alpha$-Glucosidase 저해 활성 측정 결과, 쑥(36.31 $1.56 \%)$, 곰취

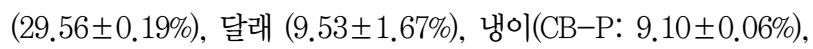

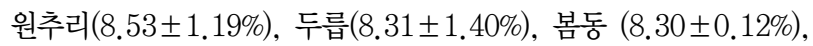
유채 $(7.52 \pm 0.79 \%)$ 의 순으로 높게 나타났다. $\mathrm{ACE}$ 저해 활성 측

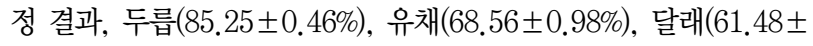

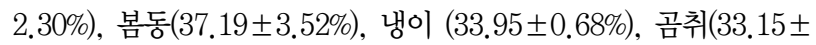

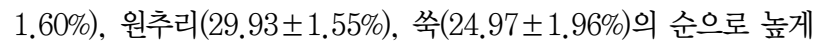
나타났다.

종합해보면, 한국인 다소비 8종 봄나물 모두 항산화 활성 및 효 소 활성을 가지고 있지만 특히, 냉이와 유채는 항산화 활성 증강에, $\alpha$-glucosidase 저해 활성이 우수한 쑥은 혈당 개선에, $\mathrm{ACE}$ 저해 활 성이 우수한 두릅은 고혈압 개선에 효과가 나타났다.

This work is part of the Hee-Jae Chung's M.S. thesis at the Kyonggi University, Seoul, Korea.

Table 6. Angiotensin converting enzyme inhibitory activity of the eight Korean spring herbs

\begin{tabular}{lc}
\hline Samples $^{1)}$ & Angiotensin converting enzyme inhibitory activity (\%) \\
LF & $33.15 \pm 1.60^{2) e f 3)}$ \\
CB-P & $33.95 \pm 0.68^{\mathrm{e}}$ \\
AM & $61.48 \pm 2.30^{\mathrm{c}}$ \\
AS & $85.25 \pm 0.46^{\mathrm{a}}$ \\
BCL & $37.19 \pm 3.52^{\mathrm{d}}$ \\
APP & $24.97 \pm 1.96^{\mathrm{g}}$ \\
HFL & $29.93 \pm 1.55^{\mathrm{f}}$ \\
BNL & $68.56 \pm 0.98^{\mathrm{b}}$ \\
\hline
\end{tabular}

LF, Gomchwi (Ligularia fischeri); CB-P, Shepherd's purse (Capsella bursa-pastoris L.); AM, Wild garlic (Allium monanthum); AS, Korean angelica tree (Aralia elata seem); BCL, Bomdong (Brassica competris L.); APP, Mugwort (Artemisia princeps pampanim); HFL, Day lily (Hemerocallis fulva L.); BNL, Rape (Brassica napus L.); ${ }^{2}$ Mean $\pm S D(n=3) ;{ }^{3}$ Different superscripts are significantly (a-g) different by Duncan's multiple range test at $p<0.05$. 


\section{Author's contribution}

K.A.J. designed all experimental design. C.H.J. collected literature and contributed to all aspects of analysis and experiment. C.H.J. wrote the manuscript with assistance from K.A.J.

\section{Author details}

Hee-Jae Chung (Graduate student), Department of Alternative Medicine, Kyonggi University, 24, Kyonggidaero, 9-gil, Seodaemoon-gu, Seoul 03752, Korea; Ae-Jung Kim (Professor), Department of Nutrition Therapy, Graduate School of Alternative Medicine, Kyonggi University, 24, Kyonggidae-ro, 9-gil, Seodaemoon-gu, Seoul 03752, Korea.

\section{References}

Ahn $\mathrm{HCH}$, Chung LN, Choe EO. In vitro antioxidant activity and $\alpha$-glucosidase and pancreatic lipase inhibitory activities of several Korean Sanchae. Korean Journal of Food Science and Technology, 47: 164-169, 2015.

Ahn WS. Korea native crop resources encyclopedia. Reason, Daejeon, pp328-329, 2009.

Bae JH, Yu SO, Kim YM, Chon SU, Kim BW, Heo BG. Physiological activity of methanol extracts from Ligularia fischeri and their hyperplasia inhibition activity of cancer cell. Journal of Bio-Environment Control, 18: 67-73, 2009.

Baron AD. Postprandial hyperglycemia and $\alpha$-glucosidase inhibitors. Diabetes Research and Clinical Practice, 40: 51-55, 1998.

Blois MS. Antioxidant determination by the use of a stable free radical. Nature, 181: 1199-1200, 1958.

Cha JY, Ahn HY, Eom KE, Park BK, Jun BS, Cho YS. Antioxidative activity of Aralia elata shoot and leaf extracts. Journal of Life Science, 19: 652-658, 2009.

Chang SK, Kim JH, Oh HS. The development of functional cold buckwheat noodles using biological activity of hot water extracts of Ligularia fischeri and Angelica gigas Nakai. Journal of the Korean Society of Food Culture, 23: 479488, 2008.

Choi BB, Lee HJ, Bang SK. Studies on the amino acid, sugar analysis and antioxidantive effect of extracts from Artemisia sp. Korean Journal of Food and Nutrition, 17:
86-91, 2004.

Choi EJ, Jeong MC, Ku KH. Effect of seasonal cabbage cultivar (Brassica rapa L. ssp. pekinesis) on the quality characteristics of salted-Kimchi cabbages during storage period. Korean Journal of Food Preservation, 22: 303313, 2015.

Choi EM, Ding Y, Nguyen HT, Park SH, Kim YH. Antioxidant activity of Gomchi (Ligularia fischeri) leaves. Food Science and Biotechnology, 16: 710-714, 2007.

Choi HS, Kang EJ, Kim KH. Analyses of essential oil and headspace compositions of Capsella bursa-pastoris Medicus by SDE and SPME Methods. Korean Journal of Food Preservation, 13: 108-114, 2006.

$\mathrm{Choi} \mathrm{CH}$. In the beginning. Daesung medical history, goyang, pp65-205, 2009.

Choi $\mathrm{CH}$. Food that saves people food that kills people. Ra's Eye, Seoul, pp159-178, 2015.

Choi JY, Lee IS, Kim SC. Effect of wild garlic on serum component of cholesterol fed rats. Journal of the Korean Applied Science and Technology, 9: 73-79, 1992.

Chung CK, Jung ME. Ethanol fraction of Aralia elata seemann enhances antioxidant activity and lowers serum lipids in rats when administered with benzo $(\alpha)$ pyrene. Biological \& Pharmaceutical Bulletin, 26: 1502-1504, 2003.

Clarke JD, Dashwood RH, Ho E. Multi-targeted prevention of cancer by sulforaphane. Cancer Letters, 269: 291-304, 2008.

Corvol P, Jeunemaitre X, Charru A, Kotelevtsev Y, Soubrier F. Role of the renin-angiotensin system in blood pressure regulation and in human hypertension: new insights from molecular genetics. In Proceedings of the 1993 Laurentian Hormone Conference, 50: 287-308, 1995.

Cushman DW, Cheung HS. Spectrophotometric assay and properties of the angiotensin-converting enzyme of rabbit lung. Biochemical Pharmacology, 20: 1637-1648, 1971.

Davis WB. Determination of flavanones in citrus fruits. Analytical Chemistry, 19: 476-478, 1947.

Fellegrini N, Ke R, Yang M, Rice-Evans C. Screening of dietary carotenoids and carotenoid-rich fruit extracts for antioxidant activities applying 2,2'-azinobis(3ethylenebenzothiazoline-6-sulfonic acid) radical cation decolorization assay. Methods in Enzymology, 299: 379389, 1999.

Fujita H, Yokoyama K, Yoshikawa M. Classification and 
antihypertensive activity of angiotensin I -converting enzyme inhibitory peptides derived from food proteins. Journal of Food Science, 65: 564-569, 2000.

Goo JO. The god of ongoji for the modern use of old agricultural books (volume 9 guhwang $\bullet$ byeokon $\bullet$ guhwalpyeon herbs 2). Rural Development Administration. Suwon, pp15-41, 2013.

Han HK, Yoon SJ, Kim GH. Effects of compositae plants on plasma glucose and lipid level in streptozotocin induced diabetic rats. Journal of the Korean Society of Food Science and Nutrition, 38: 674-682, 2009.

Ham SS. There are 57 kinds of wild greens that are excellent in anticancer effects of delicious wild greens that become medicine for eating. Academy book, Seoul, p245, 2011.

Hayes JD, Kelleher MO, Eggleston IM. The cancer chemopreventive actions of phytochemicals derived from glucosinolates. European Journal of Nutrition, 47: 73-88, 2008.

Hong JH, Jeon JL, Lee JH, Lee IS. Antioxidative properties of Artemisia princeps pamp. Journal of the Korean Society of Food Science and Nutrition, 36: 657-662, 2007.

Hwang ES, Lee HJ. Phenylethyl isothiocyanate and its $\mathrm{N}$-acetylcysteine conjugate suppress the metastasis of SK-Hep-1 human hepatoma cells. Journal of Nutritional Biochemistry, 17: 837-846, 2006.

Hwang ES. Changes in myrosinase activity and total glucosinolate levels in Korean Chinese cabbages by salting conditions. Korean Journal of Food and Cookery Science, 26: 104-109, 2010.

Jang YK. Clinical nutrition. Shinkwang Publisher, Seoul, p152, 2006.

Kang JR, Kang MJ, Choi MH, Byun HU, Shin JH. Physicochemical characteristics of ethanol extract from Artemisia Argyi H. using different preparation methods. Journal of Life Science, 27: 23-31, 2017.

Kim EJ, Choi JY, Yu MR, Kim MY, Lee SH, Lee BH. Total polyphenols, total flavonoid contents, and antioxidant activity of Korean natural and medicinal plants. Korean Journal Food Science Technology, 44: 337-342, 2012.

Kim DO, Lee CY. Considerations for the effects of antioxidant phytochemicals on human health. Korean Journal of Food Science and Technology, 53: 111-114, 2021.

Kim DS, Choi MH, Shin HJ. Polyphenol contents and antioxidant activities of domestic bamboo leaves with different extraction solvents. Journal of Advanced Engineering and Technology, 11: 7-13, 2018.

Kim HJ, Jun BS, Choi ML, Cho YS. Antioxidative activities by water-soluble extracts of morus alba and cudrania tricuspidata. The Korean Society for Applied Biological Chemistry, 43: 148-152, 2000.

Kim KC, Kim JS. Effect of varying ethanol concentrations on the extraction properties and physiological activity of Artemisia annua L.. Korean Journal of Food Science and Technology, 52: 130-137, 2020.

Kim KS, Jang YS, Lee YH, Seo TC, Choi KH, Kang DS, Kim ST, Lee KB. A rapeseed intermediate parent 'Jungmo 7002' with flowering uniformity and lodging tolerance. Korean Journal of Breeding Science, 47: 276-280, 2015.

Kim JW. Korean plant ecology bogam 2. Nature and ecology, Seoul, pp288-289, 2016.

Kim SJ, Kim GH. Plants from Ulleung island ameliorate lipid accumulation and oxidative stress in oleic acid-induced in HepG2 Cells. Korean Journal of Food Preservation, 27: 817-828, 2020.

KOSIS (Korea Disease Control and Prevention Agency, Obesity rate by city, county, and district), 2020.06.18

Kurt BZ, Gazioğlu I, Sevgi E, Sönmez F. Anticholinesterase, antioxidant, antiaflatoxigenic activities of ten edible wild plants from ordu area, Turkey. Iranian Journal of Pharmaceutical Research, 17: 1047-1056, 2018.

Kwon OJ. A case study of changes in the exercise behavior of the elderly by COVID-19. Korean Journal of Sport Psychology, 31: 123-134, 2020.

Lee AY, Hong ST, Jang YS, Lee JH. Lipid composition of Korean rapeseed (Brassica napus L.) cultivar and antioxidant capacity of phenolic extract. Journal of the Korean Society of Food Science and Nutrition, 43: 1817-1826, 2014.

Lee DW, Ko JG, Ko HR, Park SJ, Ryu HJ, Kim HCh, Cho JW, Ha JH, Ko SB. Development of 'Olle Tea' using Jeju fucoidan. Proceedings of the KAIS Fall Conference, 2011: 64-66, 2011.

Lee EH, Park HJ, Kim NH, Hong EJ, Park MJ, Lee SH, Kim MU, An BJ, Cho YJ. Biological activities of Aster scaber extracts. Korean Journal of Food Preservation, 23: 393-401,2016.

Lee JH, Park AR, Choi DW, Kim JD, Kim JC, Ahn JH, Lee HY, Choe M, Choi KP, Shin IC. Analysis of chemical compositions and electron-donating ability of 4 Korean wild sannamuls. Korean Journal of Medicinal Crop 
Science, 19: 111-116, 2011.

Lee JG. Allium monanthum, convey the fragrant taste of spring. The Jibang-Haengjung, 67: 52-55, 2018.

Lee YE. Bioactive compounds in vegetables: their role in the prevention of disease. Korean Society of Food and Cookery Science, 21: 380-398, 2005.

Lee YJ, Lee SW, Lee SCh, Park EJ. Antioxidant activities and antigenotoxic effect of ethanol extracts of Acorus gramineus, bud of Aralica elata Seem, Capsella bursapastoris, and Taraxacum officinale. Journal of Basic Sciences, 31: 45-58, 2014.

Lee YS, Ryu MJ. Antioxidant effects of Cinnamomum cassia bark extract and its effectiveness as a cosmetics ingredient. Asian Journal of Beauty and Cosmetology, 17: 69-80, 2019.

Li M, Lu W. Pharmacological research progress of Aralia elata. Medical Recapitulate, 20: 3057-3060, 2009.

Li T, Zhang X, Song Y, Liu J. A microplate-based screening method for $\alpha$-glucosidase inhibitors. Journal of Clinical Pharmacy and Therapeutics, 10: 1129-1131, 2005.

MAFRA. Development of individual authorized specific-healthfunctional food from Ligularia fischeri mixture. Ministry of Agriculture, Food and Rural Affairs, Sejong-Si, pp12-41, 2017.

Maki KC, Carson ML, Miller MP, Turowski M, Bell M, Wilder DM, Reeves MS. High-viscosity hydroxypropyl methylcellulose blunts postprandial glucose and insulin responses. Diabetes Care, 30: 1039-1043, 2007.

Martínez-González MÁ, Martín-Calvo N. The major European dietary patterns and metabolic syndrome. Reviews in Endocrine and Metabolic Disorders, 14: 265-271, 2013.

McDonald BE. Food uses and nutritional properties. In: rapeseed and canola oil, gunstone FD (Editor), Blackwell Publishing, Oxford, UK, pp131-153, 2004.

Nam HS, Jung JW, Kim DW, Ha HC. Antioxidant and antiinflammatory activities of hot water extracts of Ligularia fischeri. Korean Journal of Food Preservation, 24: 834841, 2017.

Oh JS, Ahn MJ, Han CJ, Kim HS, Kwon OR, Chung HW, Chang NS. Relationship between flavonoids intake and metabolic syndrome in Korean women with polycystic ovary syndrome. Journal of Nutrition and Health, 47: 176-185, 2014.

Peterson LA. A field guide to edible plants of eastern and central North America. Houghton Mifflin Co, Boston, USA, p26, 1997.

Pietta PG. Flavonoids as antioxidants. Journal of Natural Products, 63: 1035-1042, 2000.

RDA. 9th revision Korean food composition table. Rural Development Administration, Wanju, pp126-128, 2016.

Riaz I, Bibi Y, Ahmad N, Nisa S, Qayyum A. Evaluation of nutritional, phytochemical, antioxidant and cytotoxic potential of Capsella bursa-pastoris, a wild vegetable from potohar region of Pakistan. Kuwait Journal of Science, 48: 1-11, 2021.

Salayová A, Bedlovičová Z, Daneu N, Baláž M, Bujňáková ZL, Balážová L, Tkáčiková L. Green synthesis of silver nanoparticles with antibacterial activity using various medicinal plant extracts: morphology and antibacterial efficacy. Nanomaterials, 11: 1005, 2021.

Seo YJ, Yang IY, Yoon SJ, Kim SG, Seo SY, Won Cl, Cho WW, Lee SR, Kang HD, Yoon MY, Park JK, Yoo BS, Chang YH, Lee YS. Evaluation of quality characteristics of Brassica campetris L. treated with Environ- mentally-friendly red clay-processed materials. Journal of the Korean Society of Food Science and Nutrition, 44: 732-738, 2015.

Seo YT, Kim HJ. A study on the selection of HMR food types by dietary lifestyle. Journal of Tourism Management Research, 25: 191-209, 2021.

Singleton VL, Rossi JA. Colorimetry of total phenolics with phosphomolybdic-phosphotungstic acid reagents. American Journal of Enology and Viticulture, 16: 144-158, 1965.

Xu XD, Yang JS, Zhu ZY. Advances in the studies of saponins from Aralia. Yao Xue Xue Bao, 32: 711-720, 1997.

Yang HK, Lee DH. Achievements and challenges in a community based registration and management programme for hypertension and diabetes. Korea Disease Control and Prevention Agency, 8: 827-834, 2015.

Yoo IS, Park JM, Kim AJ. Evaluation of the physicochemical activities of frequently consumed edible flower teas in Korea. Asian Journal of Beauty and Cosmetology, 19: 289-301, 2021.

Yong SE, Park PS, Lim JM, Kwon HJ, Choi JH, Choi YH, Kim EM, Park SY. Studies on antioxidant and antidiabetic effects of fermented Cnidium officinale makino. Korea Journal of Herbology, 26: 109-113, 2011. 


\section{국문초록}

\section{한국에서 다소비 되는 봄나물류의 생리활성 연구}

정희재 ${ }^{1}$, 김애정 ${ }^{2 *}$

${ }^{1}$ 경기대학교 대체의학과, 서울, 한국

${ }^{2}$ 경기대학교 대체의학대학원 식품치료전공, 서울, 한국

목적: 본 연구에서는 국내에서 다소비 되고 있는 봄나물류 8종을 선정하고 생리활성(항산화 및 효소활성)을 평가하여 우리나라 봄 나물의 우수성을 재조명하고자 하였다. 방법: 8 종의 봄나물을 열수 추출하여 항산화 활성(total polyphenol 함량, total flavonoid 함 량, $\mathrm{DPPH}$ radical 소거능, $\mathrm{ABTS}$ radical 소거능) 및 효소 활성 ( $\alpha$-glucosidase 저해 활성, $\mathrm{ACE}$ 저해 활성)을 측정하였다. 결과: 8 종 의 다소비 봄나물 중 total polyphenol 함량은 냉이, 원추리, 곰취가 1-3위를 차지하였으며, total flavonoid 함량으로 유채, 냉이, 쑥 이 1-3위를 차지하였으며, DPPH radical 소거능은 냉이, 원추리, 유채가 1-3위를 차지하였으며, ABTS radical 소거능은 냉이, 쑥, 유채가 1-3위를 차지하였다. $\alpha$-Glucosidase 저해 활성은 쑥, 곰취, 달래가 1-3위를 차지했고, ACE 저해 활성은 두릅, 유채, 달래 가 1-3위를 차지하였다. 결론: 8 종의 봄나물 중 항산화 활성에서는 냉이와 유채, 항당뇨 활성은 쑥, 항고혈압 활성은 두릅에서 각 각의 우수한 효능이 나타나 차후 봄나물류의 현대인의 생활습관병 개선 식품 개발의 기초자료로 활용되기를 기대된다.

핵심어: 봄나물, 채소, 생활습관병, 항산화 활성, 효소 활성

\section{참고문헌}

강재란, 강민정, 최명효, 변희욱, 신정혜. 전처리 방법을 달리한 섬애약쑥 에탄올 추출물의 이화학적 특성. 생명과학회지, 27: 23-31, 2017.

구자옥. 고농서의 현대적 활용을 위한 온고이지신(제9권 구황-벽온·구활편 초본류2). 농촌진흥청. 수원, $\mathrm{pp} 15-41$, 2013.

권오정. 코로나19에 의한 노인 운동행동 변화 사례 연구. 한국스포츠심리학회지, 31: 123-134, 2020.

김경철, 김주성. 에탄올 농도 조건이 개똥쑥 추출 및 생리활성에 미치는 영향. 한국식품과학회지, 52: 130-137, 2020.

김광수, 장영석, 이영화, 서태철, 최규환, 김성택, 이경보. 개화 균일성이 좋은 내도복성 유채 중간모본 '중모 7002'. 한국 육종학회지, 47: 276-280, 2015.

김다송, 최문희, 신현재. 추출용매에 따른 국내산 대나무 잎의 폴리페놀 함량 및 항산화 활성. 공학기술논문지, $11: 7-13$, 2018.

김대옥, 이창용. 산화방지제 파이토케미컬이 건강에 미치는 영향에 대해 고려할 점. 한국식품과학회지, 53: 111-114, 2021.

김숙진, 김건희. 울릉도산 식물의 $\mathrm{HepG} 2$ 세포에서 지질 축적 및 산화 스트레스 개선 효과. 한국식품저장유통학회지, $27: 817-828,2020$.

김은진, 최주연, 유미리, 김미영, 이상현, 이복희. 자생식물과 생약자원 추출물의 폴리페놀, 플라보노이드 함량 및 항산화

활성 탐색. 한국식품과학회지, 44: 337-342, 2012.

김종원. 한국식물생태보감2. 자연과 생태, 서울, pp288-289, 2016.

김현정, 차재영, 최명락, 조영수. 뽕나무(Morus alba)와 꾸지뽕나무(Cudrania tricuspidata)의 수용성 추출물에 의한 항 산화 활성. 한국응용생명화학회지, 43: 148-152, 2000.

남호섭, 정지욱, 김도완, 하효철. 곰취 열수 추출물의 항산화 및 항염증 활성. 한국식품저장유통학회지, 24: 834-841, 2017. 
농림축산식품부. 곰취/여주 혼합추출물로부터 혈당강하 개별인정형 식품소재 개발 및 사업화 최종보고서. 농림축산식품 부, 세종시, pp12-41, 2017.

농촌진흥청. 2016 제 9 개정판 국가식품성분표 II. 농촌진흥청, 완주군, pp126-128, 2016.

배종향, 유성오, 김영민, 천상욱, 김병운, 허북구. 곰취 메탄올 추출물의 생리활성 및 암세포 증식억제 효과. 생물환경조절

학회지, 18: $67-73,2009$.

서영태, 김현주. 식생활 라이프스타일에 따른 HMR식품 유형선택에 관한 분석. 관광경영연구, 25: 191-209, 2021.

서유진, 양인용, 윤성진, 김성군, 서수영, 원주인, 조원우, 이소라, 강호덕, 윤문영, 박정극, 유병승, 장윤혁, 이영승. 친환

경 가공 황토 소재가 배추의 품질 특성에 미치는 영향. 한국식품영양과학회지, 44: 732-738, 2015.

안완식. 한국토종작물자원도감. 이유, 대전, pp328-329, 2009.

안해천, 정라나, 최은옥. 우리나라 일부 산채의 in vitro 산화 방지 활성, 알파-글루코시데이스와 췌장 라이페이스 저해 활

성. 한국식품과학회지, 47: 164-169, 2015.

양혜경, 이동한. 지역사회 일차의료기반 고혈압·당뇨병 등록관리 사업성과 및 과제. 질병관리본부, 8: 827-834, 2015.

오지수, 한찬정, 김혜숙, 권오란, 정혜원, 장남수. 한국 다낭난소증후군 환자에서 대사증후군과 식이 플라보노이드 섭취와

의 관련성. 한국영양학회지, $47: 176-185,2014$.

용시은, 박필상, 임지민, 권혁진, 최지호, 최윤희, 김은미, 박신영. 발효(醱酵) 천궁(川芦)의 항산화 및 항당뇨 활성(活性)에 관한 연구(研究). 대한본초학회지, 26: 109-113, 2011.

유인서, 박지민, 김애정. 한국에서 다소비 되고 있는 식용꽃차의 생리활성. 아시안뷰티화장품학술지, 19: 289-301, 2021.

이동원, 고정욱, 고혜리, 박소정, 류현진, 김형철, 조정원, 하진환, 고성보. 제주산 감태 추출물 후코이단을 이용한 올레차

개발. 한국산학기술학회:학술대회논문집, 2011: 64-66, 2011.

이아영, 홍순택, 장영석, 이정희. 국내산 유채 종자의 품종별 지방 조성 및 페놀 추출물의 항산화 활성. 한국식품영양과학

회지, 43: 1817-1826, 2014.

이영숙, 유민정. 계피 추출물의 항산화 효과 및 화장품소재의 응용. 아시안뷰티화장품학술지, 17: 69-80, 2019.

이영은. 채소류의 기능성. 한국식품조리과학회지, 21: 380-398, 2005.

이유정, 이선우, 이승철, 박은주. 석창포, 두릅 순, 냉이 및 민들레 에탄올 추출물의 항산화활성 및 항유전독성 분석. 기초 과학지, 31: 45-58, 2014.

이은호, 박혜진, 김나현, 홍은진, 박미정, 이선호, 김명옥, 안봉전, 조영제. 참취(Aster scaber)추출물의 생리활성. 한국식 품저장유통학회지, 23: 393-401, 2016.

이진하, 박애리, 최대운, 김종대, 김진철, 안주희, 이현용, 최면, 최근표, 신인철, 박희준. 산나물류의 식품 화학적 성분과

전자 공여능. 한국약용작물학회지, 19: 111-116, 2011.

이재건. 달래, 향긋한 봄의 맛을 전하다. 지방행정, $67: 52-55,2018$.

장유경, 임상영양학, 신광출판사, 서울, $\mathrm{p} 152,2006$.

장상근, 김준호, 오혜숙. 곰취 분말 및 당귀 열수추출물의 생리활성을 활용한 기능성 냉면의 제조. 한국식생활문화학회지, 23: $479-488,2008$

차재영, 안희영, 엄경은, 박보경, 전방실, 조영수. 두릅 순 및 잎 추출물의 항산화 효과. 한국생명과학회지, 19: $652-658$, 2009.

최병범, 이혜정, 방선권. 쑥 추출물의 아미노산, 당 분석 및 항산화 효과에 관한 연구. 한국식품영양학회지, 17: 86-91, 2004.

최은정, 정문철, 구경형. 계절별 배추 품종에 따른 절임배추의 저장중 품질 특성. 한국식품저장유통학회지, 22: $303-313$, 2015 .

최진영, 이인실, 김송전. 달래(Allium monanthum)가 콜레스테롤을 투여한 흰쥐의 혈청 성분에 미치는 영향. 한국응용과 학기술학회지, 9: 73-79, 1992. 
최철한. 본초기. 대성의학사. 고양, pp65-205, 2009.

최철한. 사람을 살리는 음식 사람을 죽이는 음식. 라의 눈, 서울, pp159-178, 2015.

최향숙, 강은진, 김건희. $\mathrm{SDE}$ 및 $\mathrm{SPME}$ 에 의한 냉이(Capsella bursa-pastoris Medicus)정유 및 Headspace 성분 분석.

한국식품저장유통학회지, 13: 108-114, 2006.

통계청(질병관리청, 시·군·구별 비만율), 2020.06.18.

한혜경, 윤수진, 김건희. 국화과 식물의 섭취가 Streptozotocin 유발 당뇨 흰쥐의 혈당과 지질 수준에 미치는 영향. 한국식 품영양과학회지, 38: 674-682, 2009.

함승시. 먹어서 약이 되는 맛있는 산나물 항암 효과가 뛰어난 산나물 57 가지. 아카데미북, 서울, $\mathrm{p} 245,2011$.

홍정희, 전정란, 이주현, 이인선. 약쑥(Artemisia princeps Pamp)의 항산화작용. 한국식품영양과학회지, 36: 657-662, 2007.

황은선. 배추 절임조건에 따른 Myrosinase 활성 및 Total Glucosinolates 함량 변화. 한국식품조리과학회지, 26: 104109, 2010. 


\section{中文摘要}

\section{韩国常用春春季野荣生物活性研究}

鄭熺載 ${ }^{1}$, 金愛貞 ${ }^{2 *}$

${ }^{1}$ 京畿大学代替医疗学科, 首尔, 韩国

2京畿大学代替医疗大学院食品治疗学科, 首尔, 韩国

目的: 本研究通过选择韩国常用的八种春季野荣并评估其生物活性来研究韩国春季草药的优越性。方法: 所选春 季野荣的热水提取物进行测定抗氧化活性（总多酚含量、总黄酮含量、1,1-二苯基 l-2-苦基肼 (DPPH) 自由基清 除活性和 2,2'-叠氮基-双-3-乙基苯并噻唑啉-6-磺酸 (ABTS) 自由基清除活性）和酶活性（ $\alpha$-葡萄糖苷酶抑制活性 和血管紧张素转化酶（ACE）抑制活性）。结果：测定总多酚含量结果显示，荠荣、黄花荣和Gomchwi分列第 一、二、三名。就总黄酮含量而言，油荣、荠荣和艾蒿分列第一、二、三名; 测定DPPH自由基清除活性结果显 示, 荠荣、黄花荣和油荣分列第一、二、三名。测定ABTS自由基清除活动结果显示, 荠荣、艾蒿和油荣分列第 一、第二和第三位。 $\alpha$-葡萄糖苷酶抑制活性结果显示, 艾蒿、五味子、野蒜分列第一、二、三名。最后, ACE抑 制活性结果显示, 韩国当归树、油荣和野蒜被归类为第一、第二和第三。结论: 从这些结果来看, 在选定的春季 野荣中, 荠荣和油荣分别在抗氧化活性、艾蒿的抗糖尿病活性和韩国当归的抗高血压活性方面表现出优异的效 果。因此, 本研究有望为未来开发利用春季野荣治疗生活习惯病的食品提供基础数据。

关键词: 春季野荣, 生活方式疾病, 饮食生活方式, 抗氧化活性, 酶活性 